\title{
Bacterial Influences on Animal Origins
}

\author{
Rosanna A. Alegado ${ }^{1}$ and Nicole King ${ }^{2}$ \\ ${ }^{1}$ Department of Oceanography, Center for Microbial Oceanography: Research and Education, Sea Grant \\ College, University of Hawai'i Mānoa, Honolulu, Hawaii 96822 \\ ${ }^{2}$ Howard Hughes Medical Institute and the Department of Molecular and Cell Biology, University \\ of California, Berkeley, California 94720 \\ Correspondence: nking@berkeley.edu
}

\begin{abstract}
Animals evolved in seas teeming with bacteria, yet the influences of bacteria on animal origins are poorly understood. Comparisons among modern animals and their closest living relatives, the choanoflagellates, suggest that the first animals used flagellated collar cells to capture bacterial prey. The cell biology of prey capture, such as cell adhesion between predator and prey, involves mechanisms that may have been co-opted to mediate intercellular interactions during the evolution of animal multicellularity. Moreover, a history of bacterivory may have influenced the evolution of animal genomes by driving the evolution of genetic pathways for immunity and facilitating lateral gene transfer. Understanding the interactions between bacteria and the progenitors of animals may help to explain the myriad ways in which bacteria shape the biology of modern animals, including ourselves.
\end{abstract}

$\mathrm{T}^{\mathrm{h}}$ he first bacteria evolved more than 3 billion years ago and dominated the biosphere continually thereafter, shaping the environment in which animals would eventually evolve more than 2 billion years later (Narbonne 2005; Knoll 2011). Because animals evolved in seas filled with bacteria and have lived in close association with bacteria throughout their evolutionary history, it is likely that diverse interactions with bacteria (including predation on bacteria, harboring bacterial commensals, and infection with bacterial pathogens) influenced animal origins. Nonetheless, although the potential contributions of global environmental change and genome evolution to animal origins have received a fair amount of attention (Hoffman et al. 1998; Knoll and Carroll 1999; Knoll 2003; King 2004; Canfield et al. 2007; Shen et al.
2008; Srivastava et al. 2008, 2010; Richter and King 2013), relatively little is known about how the interactions of animal progenitors with the abundant bacteria in their environment may have influenced the evolution of animals (McFall-Ngai 1999; Moran 2007; Hughes and Sperandio 2008; McFall-Ngai et al. 2013). We review here the current state of knowledge about ancient bacterial interactions and consider how these associations may have shaped the biology and evolution of the earliest animals.

\section{BACTERIA AND THE WORLD BEFORE ANIMALS}

The earliest fossil evidence for life on Earth is bacterial (Fig. 1). Layered macroscopic sedimentary structures known as "stromatolites" re-

Editors: Patrick J. Keeling and Eugene V. Koonin

Additional Perspectives on The Origin and Evolution of Eukaryotes available at www.cshperspectives.org

Copyright (C) 2014 Cold Spring Harbor Laboratory Press; all rights reserved; doi: 10.1101/cshperspect.a016162

Cite this article as Cold Spring Harb Perspect Biol 2014;6:a016162 
R.A. Alegado and N. King

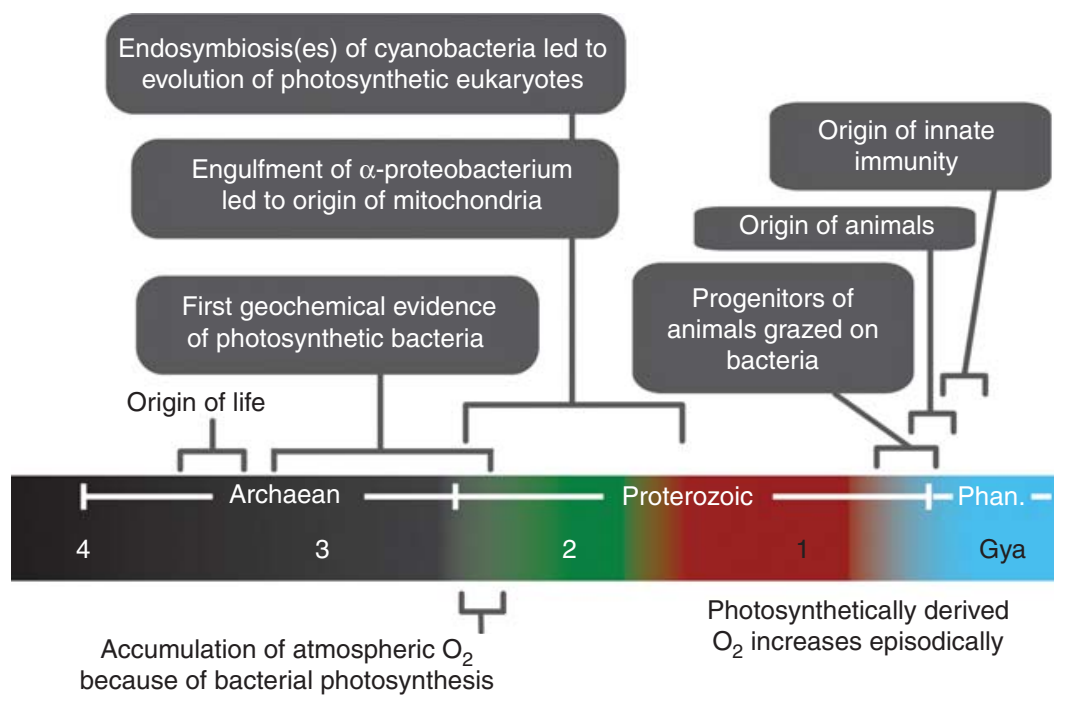

Figure 1. Major events in life's history influenced by bacteria. Bacteria have exerted critical influences on the evolution of eukaryotes and, ultimately, the origin and evolution of animals (processes indicated in gray bubbles). Bacteria and archaea contributed to the cellular and genetic building blocks for the first eukaryotic cells, and bacteria formed stable associations with early eukaryotes in the form of mitochondria and plastids. Moreover, bacteria were likely an important source of food for the progenitors of animals, as well as the first animals themselves. Finally, photosynthetic bacteria were critical for shaping the environment in which animals would evolve. The Great Oxygenation Event, estimated to have occurred 2.3 billion years ago, is likely to have been fueled by photosynthetic cyanobacteria. Moreover, photosynthetically derived oxygen, coupled with underlying geochemical processes, lead to episodic increases in oxygen levels starting in the Proterozoic. The timeline (rectangle) depicts the predominant redox state of the oceans. Anoxic surface and deep ocean waters (black) dominated the Archean Eon. During the Proterozoic Eon, surface waters became oxygenated because of mixing; however, the deep oceans remained anoxic (green). Isotopic measurements of sediments suggest that the chemistry of the ocean between $\sim 1.8$ Gya and 1 Gya was sulfidic and ferruginous (red). This period also marked the height of stromatolite abundance and diversity before their decline in the Neoproterozoic period. The Neoproterozoic is marked by the appearance of Ediacaran biota and periods of glaciation. During the Phanerozoic, more widespread oxygenation of surface and deep waters (blue) was roughly concomitant with the emergence of animals around 635 million years ago. Phan., Phanerozoic.

cord the existence of bacteria (and possibly archaea) dating back 3.45 billion years (Walter et al. 1980; Mojzsis et al. 1996; Grotzinger and Knoll 1999; Rosing 1999; Kaiser 2001; Allwood et al. 2007). Over the succeeding 2 billion years, bacteria and archaea infiltrated almost every available ecological niche and played key roles in one of life's major evolutionary transitions (Szathmáry and Smith 1995): the origin of eukaryotes. There is debate as to whether the primordial nucleus-bearing (but amitochondriate) eukaryote arose autogenously or through the fusion of a eubacterium and an archeon because genes thought to be derived from both lineages have been observed in the nuclear genomes of modern eukaryotes (Margulis 1996; Rivera and Lake 2004; Cox et al. 2008; Embley and Martin 2006; Keeling 2014; Koonin and Yutin 2014). In either event, an ancestor of all modern eukaryotes engulfed an $\alpha$-proteobacterium (Sagan 1967; Cavalier-Smith 2009), leading to the establishment of a stable endosymbiotic relationship that gave rise to the mitochondrion. Thus, the cell biology and genomes of all modern eukaryotes were built on a bacterial foundation.

Although the exact timing of eukaryotic origins is unknown, macroscopic structures found in Gabon, West Africa have been interpreted as eukaryotic fossils that are at least 2.1 billion 
years old (El Albani et al. 2010). Undisputed multicellular eukaryotes did not appear in the fossil record until $\sim 1.2$ billion years ago (Butterfield 2000). Animals apparently lagged even further behind and were not preserved in the fossil record until $\sim 635$ million years ago (Narbonne 2005; Love et al. 2009; Maloof et al. 2010; Knoll 2011), although animals may have evolved as early as 800 million years ago (Knoll and Carroll 1999; Douzery et al. 2004; Hedges et al. 2004; Peterson 2004; Erwin et al. 2011; Parfrey et al. 2011).

What caused the delay? One hypothesis posits that high levels of oxygen were a prerequisite for the evolution of multicellularity, in part, because of the limits of diffusion. Before mechanisms for active transport of oxygen evolved, an organism's size was limited by the efficiency of oxygen diffusion to inner cell layers (Erwin 1993). In addition, high levels of oxygen may have been required for the structure and function of certain classes of animal proteins that are required for multicellularity, including collagen, a key component of animal extracellular matrix (Towe 1970). Although the reasons underlying the protracted interval between the origin of eukaryotes and evolution of multicellular eukaryotes (including animals) may never be fully understood, the low concentration of oxygen in oceans and atmosphere throughout much of the Proterozoic may have suppressed the proliferation of large multicellular life (Nursall 1959; Knoll and Carroll 1999).

As a result of the photosynthetic activity of marine cyanobacteria, atmospheric oxygen levels reached what is thought to be the minimum concentration supportive of animal life, $\sim 1 \%$ of present atmospheric levels, at least 2.3 billion years ago (Budd and Jensen 2000; Kasting and Siefert 2002; Newman and Banfield 2002; Canfield et al. 2013). The emergence of the Ediacara biota $\sim 580$ million years ago, including stem animals and other multicellular eukaryotes, coincided with the oxygenation of the deep oceans, providing circumstantial evidence linking $\mathrm{pO}_{2}$ levels to the evolution of animal multicellularity (Knoll and Carroll 1999; Knoll 2003; Canfield et al. 2008; 2007). Thus, by contributing to the establishment of a prolonged stable oxic environment, bacteria inadvertently helped set the stage for animal origins.

\section{RECONSTRUCTING THE BIOLOGY OF THE FIRST ANIMALS}

The fossil record is silent when it comes to the cell and organismal biology of the last common ancestor of animals, also known as the Urmetazoan (Fig. 2) (Haeckel 1874). Nevertheless, aspects of stem animal biology can be inferred by identifying those features that are conserved among nearly all extant animals. For example, because all animals are multicellular and produce differentiated cell types, including eggs and sperm, the Urmetazoan likely also had these character traits (Nielsen 2008; Richter and King 2013). Proteins and domains required for immune defense against pathogens, including the Toll/Interleukin 1 receptor/resistance domain (TIR), the interleukin-1 receptor-like domain, and interferon regulatory factor-like proteins (required for antiviral defense), are also universal among animals and likely evolved before animal origins (Srivastava et al. 2010). Moreover, several animal developmental signaling pathways (Wnt, TGF- $\beta$, RTK, Notch, Hedgehog, and Jak-STAT) were present in the last common ancestor of animals, suggesting that the potential for elaborate developmental programs may have evolved early (Pires-daSilva and Sommer 2003; Nichols et al. 2006; Adamska et al. 2007; Manning et al. 2008; Pincus et al. 2008; Srivastava et al. 2010).

In eumetazoans, early embryogenesis is marked by a process of invagination called "gastrulation" in which an infolding of the blastoderm leads to the development of new tissue layers, including mesoderm. Like eumetazoans, some sponges produce hollow larvae that invaginate (Byrum and Martindale 2004; Leys and Eerkes-Medrano 2005; Leys and Ereskovsky 2006; Leys et al. 2009), raising the possibility that development in the Urmetazoan involved a gastrulation-like infolding of cell layers. Sponges also form epithelia that display several hallmarks of eumetazoan epithelia, including an underlying basement membrane and, in some species, proteinaceous intercellular junc- 


\section{R.A. Alegado and N. King}

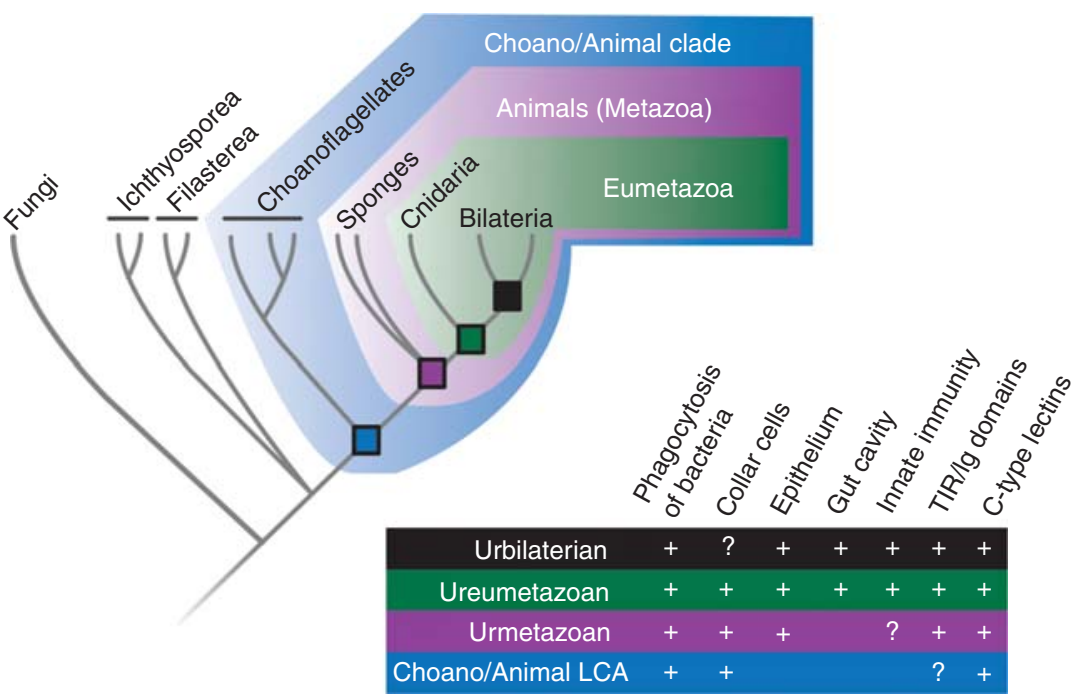

Figure 2. Ancestry and evolution of animal-bacterial interactions. Bacterial influences on the origin and evolution of animals can be inferred by comparing the organismal biology and genome content of extant choanoflagellates and diverse animals within a robust phylogenetic framework (upper left). Features shared among choanoflagellates and diverse animals were likely present in their last common ancestor (Choano/ Animal LCA, blue square; bottom right). Likewise, the biology of the Urmetazoan (purple square), Ureumetazoan (green square), and Urbilaterian (black square) can be reconstructed from features that are shared among diverse animals, eumetazoans (i.e., tissue-grade animals), and bilaterians, respectively. The conservation of collar cells in choanoflagellates, sponges, and diverse eumetazoa suggests that the progenitors of choanoflagellates and animals likely used collar cells to capture bacteria. Epithelia, an animal cell type that may be derived from an ancestral collar cell, are found in diverse animals and were likely present in the Urmetazoan. Pattern recognition protein domains, including TIR/Ig domains and C-type lectins, are expressed by diverse animals and likely evolved in stem animals, if not earlier. Interactions with bacteria were mediated solely at the cellular level in the Choano/Animal LCA and the Urmetazoan, whereas eumetazoans have evolved specialized tissue and organ systems, including the gut cavity, to harbor bacteria and regulate interactions with bacteria. Question marks indicate uncertainty about the presence or absence of a character for a given ancestor.

tions (Haeckel 1872; Falk et al. 1998; Leys and Degnan 2002; Maldonado and Bergquist 2002; Degnan et al. 2005; Nichols et al. 2009). Importantly, epithelia are essential for mediating interactions between modern animals and bacteria (e.g., by lining the gut and thereby forming a barrier to gut bacteria) (Fraune and Bosch 2010; McFall-Ngai et al. 2013). The phylogenetic distribution of epithelia and their conserved roles in regulating interactions between animals and bacteria suggests that epithelia were present and may have served similar roles in the Urmetazoan (Tyler 2003; Nielsen 2008; Nichols et al. 2009; Gilbert et al. 2012; Richter and King 2013).

Comparisons among animals and their closest relatives, the choanoflagellates, reveal additional features of Urmetazoan organismal biology (Medina et al. 2003; Philippe et al. 2004; Steenkamp et al. 2006; Carr et al. 2008; King et al. 2008; Ruiz-Trillo et al. 2008). Choanoflagellates are unicellular and colony-forming flagellates that resemble the feeding cells of sponges, called "collar cells" or choanocytes (Figs. 3A,B) (James-Clark 1868; Fjerdingstad 1961; Leys and Degnan 2002; Gonobobleva and Maldonado 2009). Each sponge collar cell and choanoflagellate cell has an ovoid cell body and single apical flagellum that is surrounded by a feeding collar of rigid, actin-filled microvilli (Karpov and Leadbeater 1997, 1998). The sinusoidal beat of the flagellum generates water currents that trap bacterial prey and organic detritus against the surface of the collar before engulfment (Lapage 1925; Pettitt et al. 2002). 

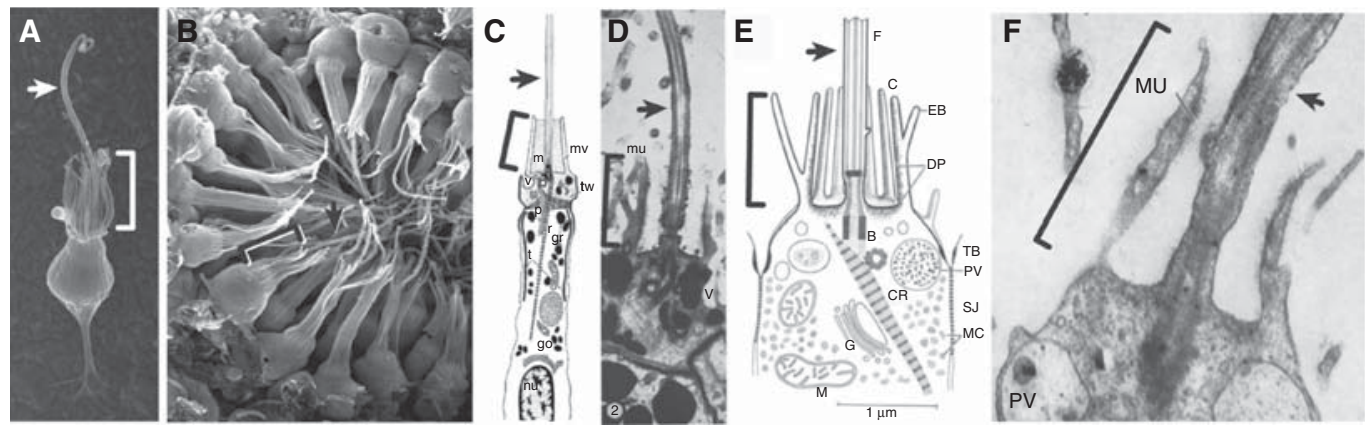

Figure 3. Variations on a collar cell theme in choanoflagellates and animals. Collar cells are typified by the presence of a single apical flagellum (indicated with an arrow) surrounded by a collar of actin-filled microvilli (indicated with a bracket). (A) Choanoflagellates are heterotrophic microeukaryotes that undulate their apical flagellum to generate water currents that draw bacteria against their actin-filled collar before phagocytosis (image of Salpingoeca rosetta courtesy of Mark Dayel. (B) Like choanoflagellates, sponge collar cells also have a single apical flagellum and collar of microvilli that they use to capture bacterial prey (image of choanocyte chamber from Oscarella carmela courtesy of Scott Nichols). (C,D) Collar cells have also been observed in cnidarians (adapted from data in Lyons 1973) and $(E, F)$ echinoderms (adapted from data in Nerrevang and Wingstrand 1970). Original labels for C: go, Golgi body; gr, granules; l, lipid; m, mucus; mv, collar microvilli; nu, nucleus; $p$, plaque, $r$, ciliary rootlet; $t$, cylindrical thickening; $t w$, terminal web; $v$, vacuole. Original labels for $D$ : mu, mucus coat; $\mathrm{v}$, vacuole. Original labels for $E$ : B, basal bodies; C, collar; DP, dense plasma; EB, external branch of microvillus; F, flagellum; G, Golgi apparatus; MC, medium-contrast clumps without membrane; $\mathrm{M}$, mitochondria; PV, phagocytic vacuole; TB, terminal bar; SJ septate junction. Original labels for F: MU, mucus; $\mathrm{PV}$, phagocytic vacuole.

The conserved structure and function of collar cells in choanoflagellates and sponges suggest that collar cells were present in the Urmetazoan and last common ancestor of choanoflagellates and animals (Brusca and Brusca 2002; Knoll 2011; McFall-Ngai et al. 2013; Richter and King 2013). Moreover, it suggests that at least some modern animal cell types evolved from an ancestral collar cell that phagocytosed bacteria.

The notion that the first animals used a filter-feeding collar cell to capture bacteria provides a useful starting point for reconstructing bacterial influences on animal origins. Although collar cells were once thought to be restricted to choanoflagellates and sponges, collar cells have now been documented in cnidarians (Lyons 1973; Goldberg and Taylor 1989b; Peterson 2004), echinoderms (Nerrevang and Wingstrand 1970; Walker 1979; Martinez et al. 1991), ascidians (Milanesi 1971), and hemichordates (Norrevang 1964). In cnidarians, some presumptive collar cells act as phagocytic feeding cells in the gastrodermis (Lyons 1973). Other cnidarian collar cells function as sensory cells in the tentacles of adults and serve unknown functions on the outer surfaces of motile larvae (Goldberg and Taylor 1989a). Epithelial cells, which are conserved in all animal lineages, may also be related to the ancient bacteria-eating collar cells of the Urmetazoan. The apical-basal polarity of epithelial cells, their possession of an apical primary cilium surrounded by microvilli, and phagocytic activity provide parallels to some of the most diagnostic features of collar cells (Norrevang 1964; Nerrevang and Wingstrand 1970; Walker 1979; Martinez et al. 1991; Singla and Reiter 2006).

Previous analyses of the paleontological record provide independent support for the idea that bacterivory was important during the origin and early evolution of animals (Stanley 1973). For example, Cambrian trace fossils hint that early bilaterians grazed on dense microbial assemblages growing on hard substrates (Dornbos et al. 2004; Bottjer 2005; Gaidos et al. 2007). The emergence and diversification of animals coincided with a rapid decline in the abundance of stromatolites leading some to hy- 
pothesize that bacteria involved in stromatolite formation were also prey targets of early animals (Garrett 1970; Awramik 1971; Walter and Heys 1985). Thus, the phylogenetic distribution of phagocytic collar cells coupled with analyses of the fossil record suggest that bacteria may have served as important food sources for early animals.

\section{CHOANOFLAGELLATE COLONY DEVELOPMENT AS A MODEL FOR ANIMAL ORIGINS}

The evolution of animals from their singlecelled ancestors is hypothesized to have involved a transition through a hollow, spherical colony of undifferentiated cells (Fig. 4A) (Haeckel 1874; Buss 1987; Grosberg and Strathmann 2007; Mikhailov et al. 2009; Knoll 2011). Many choanoflagellate species can transition between unicellular and simple multicellular (i.e., "colonial") morphologies, recapitulating the evolutionary transition that likely occurred in the animal stem lineage. Indeed, colonies formed by some choanoflagellate species resemble morula stage embryos (Fig. 4B). Moreover, just as animal embryos develop from a zygote through repeated rounds of cell division, choanoflagellate colonies develop from a single founder cell when daughter cells from each round of cell division remain attached (Fairclough et al. 2010). In diverse species of choanoflagellates, neighboring cells within colonies remain physically linked by intercellular bridges (Hibberd 1975; Karpov and Coupe 1998; Fairclough et al. 2010; Dayel et al. 2011) that leave the colony resembling the coenocytic syncytia formed by diverse invertebrates during embryogenesis (Foe and Alberts 1983; Carlson and Handel 1988; Kojima 1992; Leys 2006; Greenbaum et al. 2007; Ong and Tan 2010). The morphological parallels with animal development and the prevalence of colony formation among diverse choanoflagellates have raised the possibility that the last common ancestor of choanoflagellates and animals may have been capable of forming simple colonies (Carr et al. 2008). Thus, the last common ancestor of animals and choanoflagellates may have displayed many features of mod-
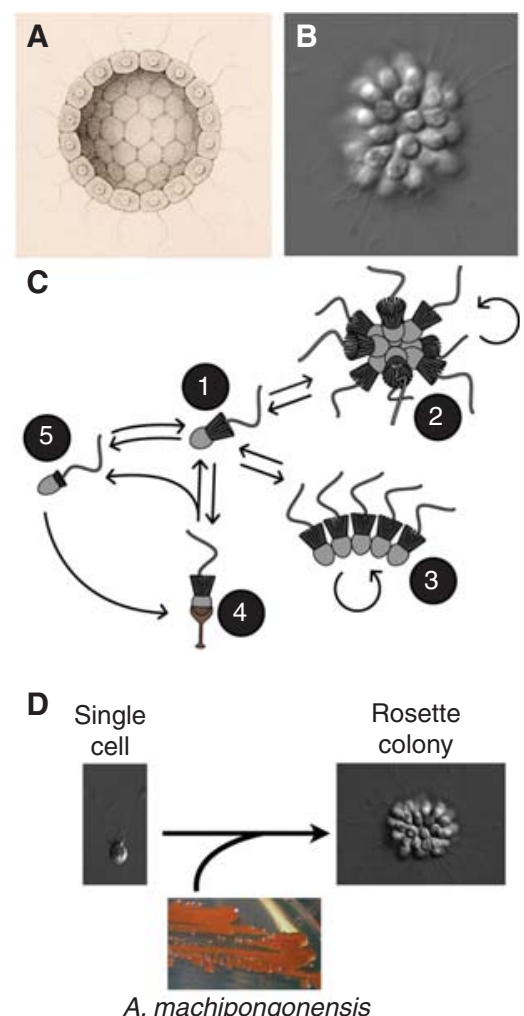

E

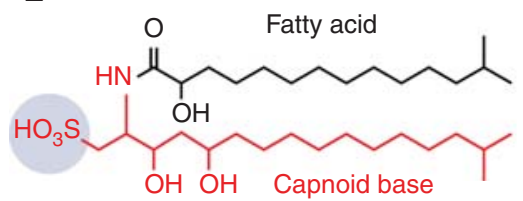

Figure 4. Choanoflagellate colony development as a model for animal origins. (A) The evolution of animals from their single-celled ancestors is hypothesized to have involved a transition through a simple, flagellated colonial form termed the Blastaea by Ernst Haeckel (1874). (B) S. rosetta produces rosetteshaped colonies that resemble Haeckel's hypothesized Blastaea (Dayel et al. 2011). (C) S. rosetta undergoes transient differentiation into slow swimming cells (1), attached "thecate" cells (4), fast swimmer cells (5), rosette colonies (2), and chain colonies (3) (adapted from data in Dayel et al. 2011). Arrows indicate differentiation events that have been observed under laboratory conditions. (D) A prey bacterium, Algoriphagus machipongonensis, produces a bioactive sulfonolipid, rosette-inducing factor-1 (RIF-1), that is sufficient to stimulate rosette colony development in S. rosetta (Alegado et al. 2012). (E) RIF-1 is composed of a fatty acid chain (black), capnoid base (red), and sulfonic acid head group (gray circle). 
ern choanoflagellate biology including collar cells, nutrient acquisition through filter feeding on bacteria, and the ability to form stable cellcell or cell-surface contacts (Steenkamp et al. 2006; Carr et al. 2008; Nielsen 2008; Richter and King 2013).

The regulation of cell differentiation during animal development may have evolved from preexisting mechanisms for regulating transient cell differentiation during the life cycles of the single-celled ancestors of animals (Bonner 1998; King 2004; Nielsen 2008). A modern example of transient cell differentiation can be found in the choanoflagellate $S$. rosetta, which produces diverse unicellular and colonial morphotypes in response to a variety of environmental cues (Fig. 4C) (Dayel et al. 2011; Alegado et al. 2012; Levin and King 2013). One of the colonial morphotypes, the rosette colony, has been shown to undergo development involving multiple layers of regulation. The first committed step toward a multicellular state occurs when a subset of solitary swimming cells differentiates, becoming competent to form a rosette colony. Rosette-competent solitary swimmers can be distinguished from morphologically identical (but rosette-incompetent) cells by the fact that they can be specifically stained by wheat germ agglutinin (WGA) lectin (Dayel et al. 2011), a commonly used marker of cell differentiation in animals (Falk et al. 1994). Although the molecular basis of the change in WGA staining is not clear, competence to form rosette colonies may be influenced by bacteria; the abundance of $\mathrm{WGA}^{+}$solitary cells increases in rapidly growing cultures that have ample bacterial prey (Dayel et al. 2011).

The second step in rosette colony development involves a developmental switch in which $\mathrm{WGA}^{+}$solitary cells undergo incomplete cytokinesis along the apical-basal axis and subsequently remain attached in a radial orientation that leads to the formation of a compact rosette colony. Transcriptome sequencing has revealed that solitary cells and colonies have distinct expression profiles and the initiation of colony development preferentially involves the up-regulation of genes that are exclusively shared by choanoflagellates and animals (Fairclough et al.
2013). Thus, rosette colonies show a number of hallmarks of animal development, including clonal multicellularity, the expression of conserved sets of regulatory genes, and morphological similarity to early animal embryos. Given the parallels between choanoflagellate rosette colony formation and animal development, elucidating the molecular mechanisms of $S$. rosetta rosette colony development may provide a window into the biology of the earliest animals.

\section{BACTERIAL CUES REGULATE A DEVELOPMENTAL SWITCH IN THE CLOSEST RELATIVES OF ANIMALS}

Despite being isolated from the environment as a rosette colony more than a decade ago (King et al. 2003), the triggers of rosette colony development in $S$. rosetta were, until recently, unknown. Early efforts to investigate the phenomenon of rosette formation were stymied by severe overgrowth of coisolated environmental bacteria and seemingly stochastic shifts in the relative abundances of different choanoflagellate cell types in laboratory cultures. This all changed serendipitously when it was discovered that serial rounds of antibiotic treatment, intended to decrease the diversity of cocultured prey bacteria, also resulted in an irreversible loss of rosette colony development in choanoflagellate cultures. Subsequent investigation revealed that rosette colony development in $S$. rosetta is regulated extrinsically by coisolated environmental bacteria (Dayel et al. 2011; Alegado et al. 2012). Thus, environmental bacteria are not just a food source for $S$. rosetta, but also regulators of its life cycle.

Inclusion of microbial cues into the regulation of development is hardly a new theme (McFall-Ngai et al. 2013). Larvae produced by diverse basal animals, including sponges (Woollacott and Hadfield 1996), cnidarians (Webster et al. 2004), bryozoans in the Bugula genus (Bertrand and Woollacott 2003; Dobretsov and Qian 2006), the ascidian Ciona intestinalis (Wieczorek and Todd 1997; Webster et al. 2004), and the polychaete Hydroides elegans (Hadfield 2011), all settle in response to uncharacterized compounds released by environ- 
mental bacteria. In addition, commensal bacteria can regulate animal development, as in the case of the light organ in the squid Euprymna scolopes (Montgomery and McFall-Ngai 1994; McFall-Ngai and Ruby 2000), and gut morphogenesis in mammals (Mazmanian et al. 2005; Bates et al. 2006). In fact, nearly all animals have stable associations with bacteria, but investigating how these interactions have shaped animal evolution has been difficult, in part, because of a dearth of tractable and phylogenetically relevant model systems.

Rosette colony development in S. rosetta is triggered by a chemical cue that originates from the bacterium A. machipongonensis, a member of the Bacteroidetes phylum (Alegado et al. 2012, 2013). Notably, Bacteroidetes bacteria regulate development and cell differentiation in at least three independent multicellular lineages: red algae, green algae, and mammals (Table 1). Thus, identifying and characterizing signaling molecules produced by A. machipongonensis may help to reveal mechanisms by which Bacteroidetes influence the development and evolution of multicellular organisms.

A bioassay based on rosette colony development revealed that a signaling molecule produced by A. machipongonensis, the previously undescribed sulfonolipid RIF-1, was sufficient to trigger rosette colony development by $S$. rosetta (Alegado et al. 2012). Sulfonolipids are structurally similar to sphingolipids, a group of bioactive molecules that regulate cell growth, apoptosis, adhesion, cell migration, and intercellular trafficking in diverse eukaryotes (Hannun and Obeid 2008). Sphingolipids, although best understood as eukaryotic signaling molecules, are also synthesized by bacteria in the Bacteroidetes phylum (Kunsman and Caldwell 1974; Lev 1979; Miyagawa et al. 1979; Yano et al. 1982; Nichols 1998; Batrakov et al. 1999), members of genus Sphingomonas (Batrakov et al. 1998; Naka et al. 2000), and Bdellovibrio genera (Steiner et al. 1973), but their presence in other bacterial groups is unknown. Sphingolipids make up a significant portion of total lipids $(40 \%-70 \%)$ in several Bacteroidetes species (Olsen and Jantzen 2001) and can even replace lipopolysaccharide in the membrane of Sphingomonas paucimobilis (Kawasaki et al. 1994), leading to the hypothesis that bacterial sphingolipids play integral roles in the cell envelope. Bacterial sphingolipids have also been documented to affect eukaryotic signaling pathways, for example, by inducing apoptosis (Minamino et al. 2003) or activating Toll-like receptor 4 (Fujiwara et al. 2013). Sulfonolipids are distinguished from sphingolipids by their sulfonic acid head group and have thus far only been isolated from bacteria (Godchaux and Leadbetter 1984; Drijber and McGill 1994; Baronio et al. 2010). The roles of sulfonolipids in bacterial physiology are unknown, but the discovery that a sulfonolipid can signal to $S$. rosetta raises the possibility that these molecules may mediate other signaling interactions between bacteria and eukaryotes.

Table 1. Signaling by Bacteroidetes bacteria influences the biology of diverse eukaryotes

\begin{tabular}{|c|c|c|c|c|c|}
\hline Eukaryote & Lineage & Bacteria/um & Signaling outcome & Molecule & References \\
\hline Human & Mammal & Bacteroides & Obesity & Unknown & Turnbaugh et al. 2009 \\
\hline Mouse & Mammal & Bacteroides & Gut maturation & PSA & Mazmanian et al. 2005 \\
\hline Zebrafish & Bony fish & Consortia & Gut maturation & Unknown & Bates et al. 2006 \\
\hline $\begin{array}{l}\text { Ciona intestinalis } \\
\text { (sea squirt) }\end{array}$ & Ascidian & $\begin{array}{c}\text { Bacteroidetes } \\
\text { consortia }\end{array}$ & $\begin{array}{l}\text { Larval settlement/ } \\
\text { metamorphosis }\end{array}$ & Unknown & $\begin{array}{l}\text { Wieczorek and Todd } \\
1997\end{array}$ \\
\hline $\begin{array}{l}\text { Acropora micro- } \\
\text { pthalma (coral) }\end{array}$ & Cnidarian & $\begin{array}{l}\text { Bacteroidetes } \\
\text { consortia }\end{array}$ & $\begin{array}{l}\text { Larval settlement/ } \\
\text { metamorphosis }\end{array}$ & Unknown & Webster et al. 2004 \\
\hline $\begin{array}{l}\text { Salpingoeca } \\
\text { rosetta }\end{array}$ & Choanoflagellate & $\begin{array}{l}\text { Algoriphagus } \\
\text { spp. }\end{array}$ & Colony formation & RIF-1 & Alegado et al. 2012 \\
\hline $\begin{array}{l}\text { Ulva pertusa } \\
\quad \text { (sea lettuce) }\end{array}$ & Green alga & $\begin{array}{l}\text { Zobellia } \\
\quad \text { uglinosa }\end{array}$ & $\begin{array}{l}\text { Thallus } \\
\text { differentiation }\end{array}$ & Thallusin & Matsuo et al. 2005 \\
\hline
\end{tabular}

PSA, polysaccharide A; RIF-1, rosette-inducing factor-1. 
It is unknown why $S$. rosetta colony development is regulated extrinsically by environmental bacteria rather than intrinsically. In the coastal estuarine environment in which $S$. rosetta was isolated, the distribution of prey bacteria within the water column fluctuates dramatically. It is possible that $S$. rosetta uses the presence or absence of distinct bacterial cues to govern cell differentiation pathways (e.g., thecate cell vs. fast swimmer vs. rosette colony) (Fig. 4C). The case of RIF-1 provides an example of how this might work in a dynamic environment with variable concentrations of a changing cast of bacteria. The initiation of rosette development in $S$. rosetta does not require direct cell contact with A. machipongonensis. Instead, RIF-1 is released into the aquatic environment where it can trigger rosette colony development over a broad range of concentrations, from $10^{-2}$ to $10^{7} \mathrm{fM}$. At these concentrations, RIF-1 is seemingly as potent as or more potent than other marine-signaling molecules (Schaefer et al. 1996; Ziegler and Forward 2007). Importantly, RIF-1 is constitutively synthesized whether or not the choanoflagellate predator is present, suggesting that its production is likely intrinsic to the biology of $A$. machipongonensis rather than a response to predation. But why would a bacterial signal induce the formation of rosette colonies? A hint comes from the fact that fluid flow around rosette colonies is higher than that around solitary cells, leading to increased contact rates with bacterial prey (Orme et al. 2001; Roper et al. 2013). Thus, the connection between bacterial signals and rosette colony development may stem from enhanced prey capture by rosette colonies under certain environmental conditions. Investigating whether bacterial signals also regulate colony development in other choanoflagellate species may provide further insight into the biology of the last common ancestor of choanoflagellates and animals.

\section{IMPLICATIONS OF A HISTORY OF BACTERIVORY ON THE GENETIC TOOLKIT FOR ANIMAL MULTICELLULARITY}

The composition of the first animal genomes was the product of both gene co-option and innovation (Rokas et al. 2003; Putnam et al. 2007; King et al. 2008; Rokas 2008; Srivastava et al. 2008; 2010; Richter and King 2013). Comparing features of animal genomes with those of choanoflagellates has to reveal the identity of those genes that arose on the stem lineage leading to animals. For example, comparisons of genomes from animals, choanoflagellates, and other relatives of animals and fungi has revealed that much of the molecular toolkit for animal development originated in the premetazoan era (Lang et al. 2002; King et al. 2003, 2008; RuizTrillo et al. 2004; Ruiz-Trillo et al. 2006; Steenkamp et al. 2006; Abedin and King 2008; Li et al. 2008; Shalchian-Tabrizi et al. 2008; Liu et al. 2009; de Mendoza et al. 2010; Sebé-Pedrós et al. 2010; Young et al. 2011; Nichols et al. 2012; Fairclough et al. 2013; Paps et al. 2013; SebéPedrós et al. 2013; Suga et al. 2013).

Because the progenitors of animals were likely bacterivores, bacterivory may have impacted genome evolution on the cusp of animal origins. For example, lateral gene transfer (LGT) from ingested prey may have provided one source of new genetic material in the progenitors of animals. As put forth by W. Ford Doolittle, the "you are what you eat" hypothesis proposes that because phagotrophy is an ancient means of obtaining nutrients and common among free-living heterotrophic protists, gene acquisition from food sources might have been a frequent basis for LGT (Doolittle 1998). Acquiring genes from the environment in this manner would require that intact DNA from donor species not only be integrated into the nucleus of a host eukaryote, but also appropriately expressed.

Choanoflagellate genomes show evidence of rampant gene acquisition through LGT. Yue et al. (2013) have calculated that $\sim 4.4 \%$ of the Monosiga brevicollis genome derives from LGT, one of the highest rates reported for unicellular eukaryotes to date. The phosphofructokinase gene from Monosiga ovata may have originated in spirochetes (Bapteste et al. 2003) and pathways for amino acid biosynthesis in M. brevicollis also seem to have been acquired from bacteria (Torruella et al. 2009; Sun and Huang 2011). Intriguingly, M. brevicollis also appears to carry 
a significant number of genes of algal origin (Nedelcu et al. 2008; Sun et al. 2010), and stramenopiles may have contributed biosilicification genes found in the genome of a loricate choanoflagellate (Marron et al. 2013) suggesting that an ancestor of extant choanoflagellates may have used both bacteria and other protists as food sources. The frequency of LGT in choanoflagellates suggests that LGT may also have been common in the phagocytic progenitors of animals.

The evolutionary history of tenuerin, a neuronal membrane protein that regulates gene transcription during development, provides one example of a gene potentially acquired through bacterivory that persists in the animal lineage (Tucker et al. 2012). The extracellular domains of teneurins mediate homotypic cell-cell adhesion and are most similar to YDrepeat proteins, adhesins found in the cell envelopes of several bacterial groups. Acquisition of such a bacterial protein may have facilitated heterotypic interactions between ancient prey bacteria and their animal predators.

The constant exposure of the first animals to environmental bacteria likely provided opportunities for new interactions, both beneficial and antagonistic. Mediating these different kinds of interactions may have required animal progenitors to evolve mechanisms for distinguishing between different types of bacteria (e.g., prey vs. pathogen). Moreover, the process of phagotrophy involves processes-including cell adhesion, incorporation, and interpretation of cues and signals from the extracellular environment, and intercellular communication-that are also fundamental requirements for multicellularity (King 2004; Grosberg and Strathmann 2007). For example, phagocytosis is initiated by contact between prey and predator cells. Animal receptors that recognize bacterial molecules include C-type lectin receptors and Toll-like receptors (Beutler 2004), some of which contain immunoglobulin domains. Choanoflagellate genomes encode C-type lectins and immunoglobulin domains (King et al. 2003, 2008; Fairclough et al. 2013) suggesting that the last common ancestor of choanoflagellates and animals also may have used these do- mains for recognition of nonself/prey ligands. C-type lectins mediate cell adhesion in animals (Weis et al. 1998), therefore, it is also conceivable that mechanisms for predator-bacteria adhesion were co-opted for intercellular adhesion during the evolution of multicellularity.

Associations between animals and bacteria also may have provided adaptive advantages during mass extinctions, such as those occurring during the Phanerozoic (McFall-Ngai et al. 2013). By extending the nutritional capacity of their hosts, commensal bacteria may have allowed animals to adapt to changing environments and expand into new ecological niches. Bacteria enhance the biology of their animal hosts in a number of ways. In sap-sucking insects, gut bacteria synthesize essential amino acids (Baumann 2005). Gut bacteria also increase the bioavailability of nutrients, such as complex carbohydrates, in some mammals (Ley et al. 2008), and microbial consortia are essential for the proper maturation of the vertebrate immune system (Mazmanian et al. 2005; Bates et al. 2006). Bacteria also exert heritable effects on host gene function by affecting epigenetic factors such as histone modification, DNA methylation, noncoding RNA, and RNA splicing (Bierne et al. 2012). Thus, bacteria likely contributed to the evolution of the Urmetazoan genome at many levels.

\section{CONCLUDING REMARKS}

As the earliest organisms that evolved on Earth, bacteria and archaea laid the biological and ecological foundations for eukaryotic origins. Evidence of our bacterial past persists today in modern eukaryotes in the form of mitochondria, plastids, membrane composition, and certain classes of nuclear genes. Moreover, the earliest animals evolved in an environment already occupied by abundant and diverse bacteria. Bacteria likely had diverse ecological interactions with the first animals, including acting as pathogens, food sources, and purveyors of chemical signals that potentially influenced the physiology and morphology of eukaryotes, including the Urmetazoan. Animals are the only obligate multicellular organisms capable 
of phagotrophy, and the bacterivorous lifestyle of the first animals potentially influenced animal genome evolution both directly through LGT and indirectly through the co-option of proteins required for prey capture into roles (e.g., intercellular adhesion and signaling) that were required for multicellularity.

The study of extant early-branching animals and their unicellular relatives promises to help illuminate the contributions of bacteria to animal origins. The conservation of collar cells in choanoflagellates and sponges suggests that bacterivory was important to the organismal biology of the first animals. Future studies of the mechanisms by which filter-feeding choanoflagellates and animals capture prey bacteria will help to explain the potential connections between bacterivory and evolution of animal multicellularity. Moreover, identifying the genes in choanoflagellates, sponges, and other early-branching animals that mediate interactions with bacteria may help to reveal the ancestry of development and innate immunity in animals. Finally, studying mechanisms by which environmental bacteria regulate the life cycles of choanoflagellates and diverse animals may begin to explain why stable associations with bacteria, once considered anathema to human health, are actually essential for the biology of most animals.

\section{ACKNOWLEDGMENTS}

We thank Tera Levin, Dan Richter, Daniel Mills, Jon Clardy, Mimi Koehl, and Andy Knoll for helpful discussions and comments on the manuscript. This review was inspired by a meeting organized by Margaret McFall-Ngai and Mike Hadfield that was held at the National Evolutionary Synthesis Center in October 2011. Financial support for the King laboratory is provided, in part, by the National Institutes of Health R01 GM099533 (N.K.) and an NIH National Research Service Award 5F32GM086054 (R.A.A.). N.K. is an Investigator in the Howard Hughes Medical Institute and a Senior Fellow in the Integrated Microbial Biodiversity Program of the Canadian Institute for Advanced Research.

\section{REFERENCES}

*Reference is also in this collection.

Abedin M, King N. 2008. The premetazoan ancestry of cadherins. Science 319: 946-948.

Adamska M, Matus DQ, Adamski M, Green K, Rokhsar DS, Martindale MQ, Degnan BM. 2007. The evolutionary origin of hedgehog proteins. Curr Biol 17: R836-R837.

Alegado RA, Brown LW, Cao S, Dermenjian RK, Zuzow R, Fairclough SR, Clardy J, King N. 2012. A bacterial sulfonolipid triggers multicellular development in the closest living relatives of animals. eLife 1: e00013.

Alegado RA, Grabenstatter JD, Zuzow R, Morris A, Huang SY, Summons RE, King N. 2013. Algoriphagus machipongonensis sp. nov., co-isolated with a colonial choanoflagellate. Int J Syst Evol Microbiol 63: 163-168.

Allwood AC, Walter MR, Burch IW, Kamber BS. 2007. 3.43 billion-year-old stromatolite reef from the Pilbara Craton of Western Australia: Ecosystem-scale insights to early life on Earth. Precamb Res 158: 198-227.

Awramik SM. 1971. Precambrian columnar stromatolite diversity: Reflection of metazoan appearance. Science 174: 825-827.

Bapteste E, Moreira D, Philippe H. 2003. Rampant horizontal gene transfer and phospho-donor change in the evolution of the phosphofructokinase. Gene 318: 185-191.

Baronio M, Lattanzio VMT, Vaisman N, Oren A, Corcelli A. 2010. The acylhalocapnines of halophilic bacteria: Structural details of unusual sulfonate sphingoids. J Lipid Res 51: $1878-1885$.

Bates JM, Mittge E, Kuhlman J, Baden KN, Cheesman SE, Guillemin K. 2006. Distinct signals from the microbiota promote different aspects of zebrafish gut differentiation. Dev Biol 297: 374-386.

Batrakov SG, Nikitin DI, Sheichenko VI, Ruzhitsky AO. 1998. A novel sulfonic-acid analogue of ceramide is the major extractable lipid of the gram-negative marine bacterium Cyclobacterium marinus WH. Biochim Biophys Acta 1391: 79-91.

Batrakov SG, Sheichenko VI, Nikitin DI. 1999. A novel glycosphingolipid from gram-negative aquatic bacteria. $B i$ ochim Biophys Acta 1440: 163-175.

Baumann P. 2005. Biology of bacteriocyte-associated endosymbionts of plant sap-sucking insects. Annu Rev Microbiol 59: 155-189.

Bertrand JF, Woollacott RM. 2003. G protein-linked receptors and induction of metamorphosis in Bugula stolonifera (Bryozoa). Invert Biol 122: 380-385.

Beutler B. 2004. Innate immunity: An overview. Mol Immunol 40: 845-859.

Bierne H, Hamon M, Cossart P. 2012. Epigenetics and bacterial infections. Cold Spring Harb Perspect Med 2: a010272.

Bonner J. 1998. The origins of multicellularity. Integr Biol 1: $27-36$.

Bottjer DJ. 2005. Geobiology and the fossil record: Eukaryotes, microbes, and their interactions. Palaeogeography, Palaeoclimatology, Palaeoecology 219: 5-21.

Brusca RC, Brusca GJ. 2002. Invertebrates. Sinauer, Sunderland, MA. 
Budd GE, Jensen S. 2000. A critical reappraisal of the fossil record of the bilaterian phyla. Biol Rev Camb Philos Soc 75: 253-295.

Buss LW. 1987. The evolution of individiuality. Princeton University Press, Princeton, NJ.

Butterfield NJ. 2000. Bangiomorpha pubescens n. gen., n. sp.: Implications for the evolution of sex, multicellularity, and the Mesoproterozoic/Neoproterozoic radiation of eukaryotes. Paleobiology 26: 386-404.

Byrum CA, Martindale MQ. 2004. Gastrulation in the Cnidaria and Ctenophora. In Gastrulation from cells to embryos. Cold Spring Harbor Laboratory Press, Cold Spring Harbor, NY, pp. 33-50.

Canfield DE, Poulton SW, Narbonne GM. 2007. Late-neoproterozoic deep-ocean oxygenation and the rise of animal life. Science 315: 92-95.

Canfield DE, Poulton SW, Knoll AH, Narbonne GM, Ross G, Goldberg T, Strauss H. 2008. Ferruginous conditions dominated later neoproterozoic deep-water chemistry. Science 321: 949-952.

Canfield DE, Ngombi-Pemba L, Hammarlund EU, Bengtson S, Chaussidon M, Gauthier-Lafaye F, Meunier A, Riboulleau A, Rollion-Bard C, Rouxel O, et al. 2013. Oxygen dynamics in the aftermath of the Great Oxidation of Earth's atmosphere. Proc Natl Acad Sci 110: 16736-16741.

Carlson JG, Handel MA. 1988. Intercellular bridges and factors determining their patterns in the grasshopper testis. J Morphol 196: 173-185.

Carr M, Leadbeater BSC, Hassan R, Nelson M, Baldauf SL. 2008. Molecular phylogeny of choanoflagellates, the sister group to Metazoa. Proc Natl Acad Sci 105: 16641 16646.

Cavalier-Smith T. 2009. Predation and eukaryote cell origins: A coevolutionary perspective. Int $\mathrm{J}$ Biochem Cell Biol 41: 307-322.

Cox CJ, Foster PG, Hirt RP, Harris SR, Embley TM. 2008. The archaebacterial origin of eukaryotes. Proc Natl Acad Sci 105: 20356-20361.

Dayel MJ, Alegado RA, Fairclough SR, Levin TC, Nichols SA, McDonald K, King N. 2011. Cell differentiation and morphogenesis in the colony-forming choanoflagellate Salpingoeca rosetta. Dev Biol 357: 73-82.

Degnan BM, Leys SP, Larroux C. 2005. Sponge development and antiquity of animal pattern formation. Integr Comp Biol 45: 335-341.

de Mendoza A, Suga H, Ruiz-Trillo I. 2010. Evolution of the MAGUK protein gene family in premetazoan lineages. BMC Evol Biol 10: 93.

Dobretsov S, Qian P-Y. 2006. Facilitation and inhibition of larval attachment of the bryozoan Bugula neritina in association with mono-species and multi-species biofilms. J Exp Marine Biol Ecol 333: 263-274.

Doolittle WF. 1998. You are what you eat: A gene transfer ratchet could account for bacterial genes in eukaryotic nuclear genomes. Trends Genet 14: 307-311.

Dornbos SQ, Bottjer DJ, Chen J-Y. 2004. Evidence for seafloor microbial mats and associated metazoan lifestyles in Lower Cambrian phosphorites of Southwest China. LETHAIA 37: 127-138.
Douzery EJP, Snell EA, Bapteste E, Delsuc F, Philippe H. 2004. The timing of eukaryotic evolution: Does a relaxed molecular clock reconcile proteins and fossils? Proc Natl Acad Sci 101: 15386-15391.

Drijber R, McGill W. 1994. Sulfonolipid content of cytophaga and flexibacter species isolated from soil and cultured under different nutrient and temperature regimes. Can J Microbiol 40: 132-139.

El Albani A, Bengtson S, Canfield DE, Bekker A, Macchiarelli R, Mazurier A, Hammarlund EU, Boulvais P, Dupuy J-J, Fontaine C, et al. 2010. Large colonial organisms with coordinated growth in oxygenated environments $2.1 \mathrm{Gyr}$ ago. Nature 466: 100-104.

Embley TM, Martin W. 2006. Eukaryotic evolution, changes and challenges. Nat Cell Biol 440: 623-630.

Erwin DH. 1993. The origin of metazoan development: A palaeobiological perspective. Biol J Linnean Soc 50: 255 274.

Erwin DH, Laflamme M, Tweedt SM, Sperling EA, Pisani D, Peterson KJ. 2011. The Cambrian conundrum: Early divergence and later ecological success in the early history of animals. Science 334: 1091-1097.

Fairclough SR, Dayel MJ, King N. 2010. Multicellular development in a choanoflagellate. Curr Biol 20: R875-R876.

Fairclough SR, Chen Z, Kramer E, Zeng Q, Young S, Robertson HM, Begovic E, Richter DJ, Russ C, Westbrook MJ, et al. 2013. Premetazoan genome evolution and the regulation of cell differentiation in the choanoflagellate Salpingoeca rosetta. Genome Biol 14: R15.

Falk P, Roth KA, Gordon JI. 1994. Lectins are sensitive tools for defining the differentiation programs of mouse gut epithelial cell lineages. Am J Physiol 266: G987-G1003.

Falk PG, Hooper LV, Midtvedt T, Gordon JI. 1998. Creating and maintaining the gastrointestinal ecosystem: What we know and need to know from gnotobiology. Microbiol Mol Biol Rev 62: 1157-1170.

Fjerdingstad EJ. 1961. The ultrastructure of choanocyte collars in Spongilla lacustris (L.). Z Zellforschung 53: 645657.

Foe VE, Alberts BM. 1983. Studies of nuclear and cytoplasmic behaviour during the five mitotic cycles that precede gastrulation in Drosophila embryogenesis. J Cell Sci 61: 31-70.

Fraune S, Bosch TCG. 2010. Why bacteria matter in animal development and evolution. Bioessays 32: 571-580.

Fujiwara N, Porcelli SA, Naka T, Yano I, Maeda S, Kuwata H, Akira S, Uematsu S, Takii T, Ogura H, et al. 2013. Bacterial sphingophospholipids containing non-hydroxy fatty acid activate murine macrophages via Toll-like receptor 4 and stimulate bacterial clearance. Biochim Biophys Acta 1831: 1177-1184.

Gaidos E, Dubuc T, Dunford M, McAndrew P, PadillaGamino J, Studer B, Weersing K, Stanley S. 2007. The Precambrian emergence of animal life: A geobiological perspective. Geobiology 5: 351-373.

Garrett P. 1970. Phanerozoic stromatolites: Noncompetitive ecologic restriction by grazing and burrowing animals. Science 169: 171-173.

Gilbert SF, Sapp J, Tauber AI. 2012. A symbiotic view of life: We have never been individuals. Q Rev Biol 87: 325-341. 
Godchaux W, Leadbetter ER. 1984. Sulfonolipids of gliding bacteria. Structure of the $\mathrm{N}$-acylaminosulfonates. J Biol Chem 259: 2982-2990.

Goldberg WM, Taylor GT. 1989a. Cellular structure and ultrastructure of the black coral Antipathes aperta: 1 . Organization of the tentacular epidermis and nervous system. J Morphol 202: 239-253.

Goldberg WM, Taylor GT. 1989b. Cellular structure and ultrastructure of the black coral Antipathes aperta: 2. The gastrodermis and its collar cells. J Morphol 202: 255-269.

Gonobobleva E, Maldonado M. 2009. Choanocyte ultrastructure in Halisarca dujardini (Demospongiae, Halisarcida). J Morphol 270: 615-627.

Greenbaum MP, Ma L, Matzuk MM. 2007. Conversion of midbodies into germ cell intercellular bridges. Dev Biol 305: 389-396.

Grosberg RK, Strathmann RR. 2007. The evolution of multicellularity: A minor major transition? Annu Rev Ecol Evol Syst 38: 621-654.

Grotzinger JP, Knoll AH. 1999. Stromatolites in Precambrian carbonates: Evolutionary mileposts or environmental dipsticks? Annu Rev Earth Planet Sci 27: 313-358.

Hadfield MG. 2011. Biofilms and marine invertebrate larvae: What bacteria produce that larvae use to choose settlement sites. Ann Rev Mar Sci 3: 453-470.

Haeckel E. 1872. Die Kalkschwamme [The calcareous sponges]. Georg Reimer, Berlin.

Haeckel E. 1874. Memoirs: The Gastraea-theory, the phylogenetic classification of the animal kingdom and the homology of the germ-lamellae. J Cell Sci s2-s14: 223-247.

Hannun YA, Obeid LM. 2008. Principles of bioactive lipid signalling: Lessons from sphingolipids. Nat Rev Mol Cell Biol 9: 139-150.

Hedges SB, Blair JE, Venturi ML, Shoe JL. 2004. A molecular timescale of eukaryote evolution and the rise of complex multicellular life. BMC Evol Biol 4: 2.

Hibberd DJ. 1975. Observations on the ultrastructure of the choanoflagellate Codosiga botrytis (Ehr.) Saville-Kent with special reference to the flagellar apparatus. J Cell Sci 17: 191-219.

Hoffman P, Kaufman A, Halverson G, Schrag D. 1998. A neoproterozoic snowball earth. Science 281: 1342-1346.

Hughes DT, Sperandio V. 2008. Inter-kingdom signalling: Communication between bacteria and their hosts. Nat Rev Micro 6: 111-120.

James-Clark H. 1868. On the spongiae ciliatae as infusoria flagellata; or observations on the structure, animality, and relationship of Leucosolenia botryoides, Bowerbank Memoirs Boston Soc Hist 1: 133-142, 188-215, 250-264.

Kaiser D. 2001. Building a multicellular organism. Anпu Rev Genet 35: 103-123.

Karpov SA, Coupe SJ. 1998. A revision of choanoflagellate genera Kentrosiga Schiller, 1953 and Desmarella Kent, 1880. Acta Protozool 37: 23-27.

Karpov SA, Leadbeater BSC. 1997. Cell and nuclear division in a freshwater choanoflagellate, Monosiga ovata Kent. Eur J Protistol 33: 323-334.
Karpov SA, Leadbeater BSC. 1998. Cytoskeleton structure and composition in choanoflagellates. J Eukaryot Microbiol 45: 361-367.

Kasting JF, Siefert JL. 2002. Life and the evolution of earth's atmosphere. Science 296: 1066-1068.

Kawasaki S, Moriguchi R, Sekiya K, Nakai T, Ono E, Kume K, Kawahara K. 1994. The cell envelope structure of the lipopolysaccharide-lacking gram-negative bacterium Sphingomonas paucimobilis. J Bacteriol 176: 284-290.

* Keeling PJ. 2014. The impact of history on our perception of evolutionary events: Endosymbiosis and the origin of eukaryotic complexity. Cold Spring Harb Perspect Biol 6: a016196.

King N. 2004. The unicellular ancestry of animal development. Dev Cell 7: 313-325.

King N, Hittinger CT, Carroll SB. 2003. Evolution of key cell signaling and adhesion protein families predates animal origins. Science 301: 361-363.

King N, Westbrook MJ, Young SL, Kuo A, Abedin M, Chapman J, Fairclough S, Hellsten U, Isogai Y, Letunic I, et al. 2008. The genome of the choanoflagellate Monosiga brevicollis and the origin of metazoans. Nature 451: $783-$ 788.

Knoll AH. 2003. The geological consequences of evolution. Geobiology 1: 3-14.

Knoll AH. 2011. The multiple origins of complex multicellularity. Annu Rev Earth Planet Sci 39: 217-239.

Knoll AH, Carroll SB. 1999. Early animal evolution: Emerging views from comparative biology and geology. Science 284: 2129-2137.

Kojima Y. 1992. Ultrastructure of goat testes: Intercellular bridge between germ cells. J Vet Med Sci 54: 213-219.

* Koonin EV, Yutin N. 2014. The dispersed archaeal eukaryome and the complex archaeal ancestor of eukaryotes. Cold Spring Harb Perspect Biol 6: a016188.

Kunsman JE, Caldwell DR. 1974. Comparison of the sphingolipid content of rumen Bacteroides species. Appl Microbiol 28: 1088-1089.

Lang BF, O'Kelly C, Nerad T, Gray MW, Burger G. 2002. The closest unicellular relatives of animals. Curr Biol 12: $1773-1778$.

Lapage G. 1925. Notes on the choanoflagellate, Codosiga botrytis, Ehrbg. Q J Microsc Sci 69: 471-508.

Lev M. 1979. Sphingolipid biosynthesis and vitamin K metabolism in Bacteroides melaninogenicus. Am J Clin Nutr 32: $179-186$.

Levin TC, King N. 2013. Evidence for sex and recombination in the choanoflagellate Salpingoeca rosetta. Curr Biol 23: $2176-2180$.

Ley RE, Hamady M, Lozupone C, Turnbaugh PJ, Ramey RR, Bircher JS, Schlegel ML, Tucker TA, Schrenzel MD, Knight R, et al. 2008. Evolution of mammals and their gut microbes. Science 320: 1647-1651.

Leys SP. 2006. Embryogenesis in the glass sponge Oopsacas minuta: Formation of syncytia by fusion of blastomeres. Integr Comp Biol 46: 104-117.

Leys SP, Degnan BM. 2002. Embryogenesis and metamorphosis in a haplosclerid demosponge: Gastrulation and transdifferentiation of larval ciliated cells to choanocytes. Invert Biol 121: 171-189. 
Leys SP, Eerkes-Medrano D. 2005. Gastrulation in calcareous sponges: In search of Haeckel's Gastraea. Integr Comp Biol 45: $342-351$.

Leys SP, Ereskovsky AV. 2006. Embryogenesis and larval differentiation in sponges. Can J Zool 84: 262-287.

Leys SP, Nichols SA, Adams EDM. 2009. Epithelia and integration in sponges. Integr Comp Biol 49: 167-177.

Li W, Young SL, King N, Miller WT. 2008. Signaling properties of a non-metazoan Src kinase and the evolutionary history of Src negative regulation. J Biol Chem 283: 15491-15501.

Liu Y, Steenkamp ET, Brinkmann H, Forget L, Philippe H, Lang BF. 2009. Phylogenomic analyses predict sistergroup relationship of nucleariids and fungi and paraphyly of zygomycetes with significant support. BMC Evol Biol 9: 272.

Love GD, Grosjean E, Stalvies C, Fike DA, Grotzinger JP, Bradley AS, Kelly AE, Bhatia M, Meredith W, Snape CE, et al. 2009. Fossil steroids record the appearance of Demospongiae during the Cryogenian period. Nature 457: $718-721$.

Lyons KM. 1973. Collar cells in planula and adult tentacle ectoderm of the solitary coral Balanophyllia regia (Anthozoa Eupsammiidae). Z Zellforsch Mikrosk Anat 145: $57-74$.

Maldonado M, Bergquist PR. 2002. Phylum Porifera. In Atlas of marine invertebrate larvae (ed. Young CM, Sewell MA, Rice ME), pp. 21-50. Academic, San Diego.

Maloof AC, Rose CV, Beach R, Samuels BM, Calmet CC, Erwin DH, Poirier GR, Yao N, Simons FJ. 2010. Possible animal-body fossils in pre-Marinoan limestones from South Australia. Nat Geosci 3: 653-659.

Manning G, Young SL, Miller WT, Zhai Y. 2008. The protist, Monosiga brevicollis, has a tyrosine kinase signaling network more elaborate and diverse than found in any known metazoan. Proc Natl Acad Sci 105: 9674-9679.

Margulis L. 1996. Archaeal-eubacterial mergers in the origin of Eukarya: Phylogenetic classification of life. Proc Natl Acad Sci 93: 1071-1076.

Marron AO, Alston MJ, Heavens D, Akam M, Caccamo M, Holland PWH, Walker G. 2013. A family of diatom-like silicon transporters in the siliceous loricate choanoflagellates. Proc Biol Sci 280: 20122543.

Martinez A, Lopez J, Villaro AC, Sesma P. 1991. Choanocytelike cells in the digestive system of the starfish Marthasterias glacialis (Echinodermata). J Morphol 208: 215225.

Matsuo Y, Imagawa H, Nishizawa M, Shizuri Y. 2005. Isolation of an algal morphogenesis inducer from a marine bacterium. Science 307: 1598.

Mazmanian SK, Liu CH, Tzianabos AO, Kasper DL. 2005. An immunomodulatory molecule of symbiotic bacteria directs maturation of the host immune system. Cell 122: $107-118$.

McFall-Ngai M. 1999. Consequences of evolving with bacterial symbionts: Insights from the squid-vibrio associations. Annu Rev Ecol Syst 30: 235-256.

McFall-Ngai MJ, Ruby EG. 2000. Developmental biology in marine invertebrate symbioses. Curr Opin Microbiol 3: 603-607.
McFall-Ngai M, Hadfield MG, Bosch TCG, Carey HV, Domazet-Loso T, Douglas AE, Dubilier N, Eberl G, Fukami T, Gilbert SF, et al. 2013. Animals in a bacterial world, a new imperative for the life sciences. Proc Natl Acad Sci 110: $3229-3236$.

Medina M, Collins AG, Taylor JW, Valentine JW, Lipps JH, Amaral-Zettler L, Sogin ML. 2003. Phylogeny of Opisthokonta and the evolution of multicellularity and complexity in Fungi and Metazoa. Int J Astrobiol 2: 203-211.

Mikhailov KV, Konstantinova AV, Nikitin MA, Troshin PV, Rusin LY, Lyubetsky VA, Panchin YV, Mylnikov AP, Moroz LL, Kumar S, et al. 2009. The origin of Metazoa: A transition from temporal to spatial cell differentiation. Bioessays 31: $758-768$.

Milanesi C. 1971. Choanocytes in endostyle of BotryllusSchlosseri (Pallas) Ascidiacea Stolidobranchiata. J Submicrosc Cytol 3: 359-363.

Minamino M, Sakaguchi I, Naka T, Ikeda N, Kato Y, Tomiyasu I, Yano I, Kobayashi K. 2003. Bacterial ceramides and sphingophospholipids induce apoptosis of human leukaemic cells. Microbiology 149: 2071-2081.

Miyagawa E, Azuma R, Suto T, Yano I. 1979. Occurrence of free ceramides in Bacteroides fragilis NCTC 9343. J Biochem 86: 311-320.

Mojzsis SJ, Arrhenius G, McKeegan KD, Harrison TM, Nutman AP, Friend CR. 1996. Evidence for life on Earth before 3,800 million years ago. Nature 384: 55-59.

Montgomery MK, McFall-Ngai MJ. 1994. Bacterial symbionts induce host organ morphogenesis during early postembryonic development of the squid Euprymna scolopes. Development 120: 1719-1729.

Moran NA. 2007. Symbiosis as an adaptive process and source of phenotypic complexity. Proc Natl Acad Sci 104: $8627-8633$.

Naka T, Fujiwara N, Yabuuchi E, Doe M, Kobayashi K, Kato Y, Yano I. 2000. A novel sphingoglycolipid containing galacturonic acid and 2-hydroxy fatty acid in cellular lipids of Sphingomonas yanoikuyae. J Bacteriol 182: 26602663.

Narbonne GM. 2005. The Ediacara biota: Neoproterozoic origin of animals and their ecosystems. Annu Rev Earth Planet Sci 33: 421-442.

Nedelcu AM, Miles IH, Fagir AM, Karol K. 2008. Adaptive eukaryote-to-eukaryote lateral gene transfer: Stress-related genes of algal origin in the closest unicellular relatives of animals. J Evol Biol 21: 1852-1860.

Nerrevang A, Wingstrand KG. 1970. On the occurrence and structure of choanocyte-like cells in some echinoderms. Acta Zoologica 51: 249-270.

Newman DK, Banfield JF. 2002. Geomicrobiology: How molecular-scale interactions underpin biogeochemical systems. Science 296: 1071-1077.

Nichols FC. 1998. Novel ceramides recovered from Porphyromonas gingivalis: Relationship to adult periodontitis. $J$ Lipid Res 39: 2360-2372.

Nichols SA, Dirks W, Pearse JS, King N. 2006. Early evolution of animal cell signaling and adhesion genes. Proc Natl Acad Sci 103: 12451-12456.

Nichols SA, Dayel M, King N. 2009. Genomic, phylogenetic, and cell biological insights into metazoan origins. In Animal Evolution: Genomes, Fossils, and Trees (ed. Telford 
MJ, Littlewood DTJ), pp. 24-32. Oxford University Press, Oxford.

Nichols SA, Roberts BW, Richter DJ, Fairclough SR, King N. 2012. Origin of metazoan cadherin diversity and the antiquity of the classical cadherin/ $\beta$-catenin complex. Proc Natl Acad Sci 109: 13046-13051.

Nielsen C. 2008. Six major steps in animal evolution: Are we derived sponge larvae? Evol Dev 10: 241-257.

Norrevang A. 1964. Choanocytes in the skin of Harrimania kupfferi (Enteropneusta). Nature 204: 398-399.

Nursall JR. 1959. Oxygen as a prerequisite to the origin of the Metazoa. Nature 183: 1170-1172.

Olsen I, Jantzen E. 2001. Sphingolipids in bacteria and fungi. Anaerobe 7: 103-112.

Ong S, Tan C. 2010. Germline cyst formation and incomplete cytokinesis during Drosophila melanogaster oogenesis. Dev Biol 337: 84-98.

Orme B, Otto SR, Blake JR. 2001. Enhanced efficiency of feeding and mixing due to chaotic flow patterns around choanoflagellates. IMA J Math Appl Med Biol 18: 293325.

Paps J, Medina-Chacón LA, Marshall W, Suga H, Ruiz-Trillo I. 2013. Molecular phylogeny of unikonts: New insights into the position of apusomonads and ancyromonads and the internal relationships of opisthokonts. Protist 164: $2-12$.

Parfrey LW, Lahr DJG, Knoll AH, Katz LA. 2011. Estimating the timing of early eukaryotic diversification with multigene molecular clocks. Proc Natl Acad Sci 108: 1362413629.

Peterson KJ. 2004. Estimating metazoan divergence times with a molecular clock. Proc Natl Acad Sci 101: 65366541.

Pettitt ME, Orme B, Blake JR, Leadbeater B. 2002. The hydrodynamics of filter feeding in choanoflagellates. Eur J Protistol 38: 313-332.

Philippe H, Snell EA, Bapteste E, Lopez P, Holland PWH, Casane D. 2004. Phylogenomics of eukaryotes: Impact of missing data on large alignments. Mol Biol Evol 21: 1740 1752.

Pincus D, Letunic I, Bork P, Lim WA. 2008. Evolution of the phospho-tyrosine signaling machinery in premetazoan lineages. Proc Natl Acad Sci 105: 9680-9684.

Pires-daSilva A, Sommer R. 2003. The evolution of signalling pathways in animal development. Nat Rev Genet 4: 39-49.

Putnam NH, Srivastava M, Hellsten U, Dirks B, Chapman J, Salamov A, Terry A, Shapiro H, Lindquist E, Kapitonov VV, et al. 2007. Sea anemone genome reveals ancestral eumetazoan gene repertoire and genomic organization. Science 317: 86-94.

Richter DJ, King N. 2013. The genomic and cellular foundations of animal origins. Annu Rev Genet 47: 509-537.

Rivera MC, Lake JA. 2004. The ring of life provides evidence for a genome fusion origin of eukaryotes. Nature 431: $152-155$.

Rokas A. 2008. The origins of multicellularity and the early history of the genetic toolkit for animal development. Annu Rev Genet 42: 235-251.
Rokas A, King N, Finnerty J, Carroll SB. 2003. Conflicting phylogenetic signals at the base of the metazoan tree. Evol Dev 5: 346-359.

Roper M, Dayel MJ, Pepper RE, Koehl MAR. 2013. Cooperatively generated stresslet flows supply fresh fluid to multicellular choanoflagellate colonies. Phys Rev Lett 110: 228104

Rosing M. 1999. 13C-Depleted carbon microparticles in $>3700$-Ma sea-floor sedimentary rocks from west greenland. Science 283: 674-676.

Ruiz-Trillo I, Inagaki Y, Davis LA, Sperstad S, Landfald B, Roger AJ. 2004. Capsaspora owczarzaki is an independent opisthokont lineage. Curr Biol 14: R946-R947.

Ruiz-Trillo I, Lane CE, Archibald JM, Roger AJ. 2006. Insights into the evolutionary origin and genome architecture of the unicellular opisthokonts Capsaspora owczarzaki and Sphaeroforma arctica. J Eukaryot Microbiol 53: 379-384.

Ruiz-Trillo I, Roger AJ, Burger G, Gray MW, Lang BF. 2008. A phylogenomic investigation into the origin of metazoa. Mol Biol Evol 25: 664-672.

Sagan L. 1967. On the origin of mitosing cells. J Theor Biol 14: $225-274$.

Schaefer AL, Hanzelka BL, Eberhard A, Greenberg EP. 1996. Quorum sensing in Vibrio fischeri: Probing autoinducerLuxR interactions with autoinducer analogs. J Bacteriol 178: $2897-2901$.

Sebé-Pedrós A, Roger AJ, Lang FB, King N, Ruiz-Trillo I. 2010. Ancient origin of the integrin-mediated adhesion and signaling machinery. Proc Natl Acad Sci 107: 1014210147.

Sebé-Pedrós A, Burkhardt P, Sánchez-Pons N, Fairclough SR, Lang BF, King N, Ruiz-Trillo I. 2013. Insights into the origin of metazoan filopodia and microvilli. Mol Biol Evol 30: 2013-2023.

Shalchian-Tabrizi K, Minge MA, Espelund M, Orr R, Ruden T, Jakobsen KS, Cavalier-Smith T. 2008. Multigene phylogeny of choanozoa and the origin of animals. PLoS ONE 3: e2098.

Shen Y, Zhang T, Hoffman PF. 2008. On the coevolution of Ediacaran oceans and animals. Proc Natl Acad Sci 105: 7376-7381.

Singla V, Reiter JF. 2006. The primary cilium as the cell's antenna: Signaling at a sensory organelle. Science 313: 629-633.

Srivastava M, Begovic E, Chapman J, Putnam NH, Hellsten U, Kawashima T, Kuo A, Mitros T, Salamov A, Carpenter ML, et al. 2008. The Trichoplax genome and the nature of placozoans. Nature 454: 955-960.

Srivastava M, Simakov O, Chapman J, Fahey B, Gauthier MEA, Mitros T, Richards GS, Conaco C, Dacre M, Hellsten U, et al. 2010. The Amphimedon queenslandica genome and the evolution of animal complexity. Nature 466: $720-726$.

Stanley SM. 1973. An ecological theory for the sudden origin of multicellular life in the late precambrian. Proc Natl Acad Sci 70: 1486-1489.

Steenkamp ET, Wright J, Baldauf SL. 2006. The protistan origins of animals and fungi. Mol Biol Evol 23: 93-106. 


\section{R.A. Alegado and N. King}

Steiner S, Conti SF, Lester RL. 1973. Occurrence of phosphonosphingolipids in Bdellovibrio bacteriovorus strain UKi2. J Bacteriol 116: 1199-1211.

Suga H, Chen Z, de Mendoza A, Sebé-Pedrós A, Brown MW Kramer E, Carr M, Kerner P, Vervoort M, Sánchez-Pons N, et al. 2013. The Capsaspora genome reveals a complex unicellular prehistory of animals. Nat Commun 4: 2325.

Sun G, Huang J. 2011. Horizontally acquired DAP pathway as a unit of self-regulation. J Evol Biol 24: 587-595.

Sun G, Yang Z, Ishwar A, Huang J. 2010. Algal genes in the closest relatives of animals. Mol Biol Evol 27: 2879-2889.

Szathmáry E, Smith JM. 1995. The major evolutionary transitions. Nature 374: 227-232.

Torruella G, Suga H, Riutort M, Peretó J, Ruiz-Trillo I. 2009. The evolutionary history of lysine biosynthesis pathways within eukaryotes. J Mol Evol 69: 240-248.

Towe KM. 1970. Oxygen-collagen priority and the early metazoan fossil record. Proc Natl Acad Sci 65: 781.

Tucker RP, Beckmann J, Leachman NT, Schöler J, ChiquetEhrismann R. 2012. Phylogenetic analysis of the teneurins: Conserved features and premetazoan ancestry. $\mathrm{Mol}$ Biol Evol 29: 1019-1029.

Turnbaugh PJ, Hamady M, Yatsunenko T, Cantarel BL, Duncan A, Ley RE, Sogin ML, Jones WJ, Roe BA, Affourtit JP, et al. 2009. A core gut microbiome in obese and lean twins. Nature 457: 480-484.

Tyler S. 2003. Epithelium-The primary building block for metazoan complexity. Integr Comp Biol 43: 55-63.

Walker CW. 1979. Ultrastructure of the somatic portion of the gonads in asteroids, with emphasis on flagellated-collar cells and nutrient transport. J Morphol 162: $127-161$.
Walter MR, Heys GR. 1985. Links between the rise of the metazoa and the decline of stromatolites. Precamb Res 29: 149-174.

Walter MR, Buick R, Dunlop J. 1980. Stromatolites 3,4003,500 myr old from the North-Pole Area, Western Australia. Nature 284: 443-445.

Webster NS, Smith LD, Heyward AJ, Watts JEM, Webb RI, Blackall LL, Negri AP. 2004. Metamorphosis of a scleractinian coral in response to microbial biofilms. Appl Environ Microbiol 70: 1213-1221.

Weis WI, Taylor ME, Drickamer K. 1998. The C-type lectin superfamily in the immune system. Immunol Rev 163: 19-34.

Wieczorek SK, Todd CD. 1997. Inhibition and facilitation of bryozoan and ascidian settlement by natural multispecies biofilms: Effects of film age and the roles of active and passive larval attachment. Marine Biol 128: 463-473.

Woollacott RM, Hadfield MG. 1996. Induction of metamorphosis in larvae of a sponge. Invert Biol 115: 257-262.

Yano I, Tomiyasu I, Yabuuchi E. 1982. Long chain base composition of strains of three species of Sphingobacterium gen. nov. FEMS Microbiol Lett 15: 303-307.

Young SL, Diolaiti D, Conacci-Sorrell M, Ruiz-Trillo I, Eisenman RN, King N. 2011. Premetazoan ancestry of the Myc-Max network. Mol Biol Evol 28: 2961-2971.

Yue J, Sun G, Hu X, Huang J. 2013. The scale and evolutionary significance of horizontal gene transfer in the choanoflagellate Monosiga brevicollis. BMC Genomics 14: 729.

Ziegler TA, Forward RB. 2007. Larval release behaviors in the Caribbean spiny lobster, Panulirus argus: Role of peptide pheromones. J Chem Ecol 33: 1795-1805. 


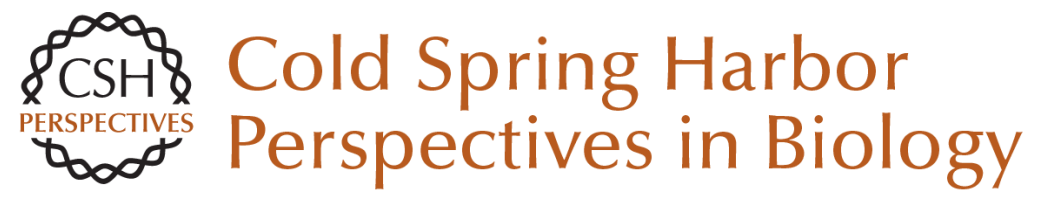

\section{Bacterial Influences on Animal Origins}

Rosanna A. Alegado and Nicole King

Cold Spring Harb Perspect Biol 2014; doi: 10.1101/cshperspect.a016162 originally published online October 3, 2014

\section{Subject Collection The Origin and Evolution of Eukaryotes}

The Persistent Contributions of RNA to Eukaryotic Gen(om)e Architecture and Cellular Function Jürgen Brosius

Green Algae and the Origins of Multicellularity in the Plant Kingdom James G. Umen

The Archaeal Legacy of Eukaryotes: A Phylogenomic Perspective Lionel Guy, Jimmy H. Saw and Thijs J.G. Ettema

Origin and Evolution of the Self-Organizing Cytoskeleton in the Network of Eukaryotic Organelles Gáspár Jékely

On the Age of Eukaryotes: Evaluating Evidence from Fossils and Molecular Clocks

Laura Eme, Susan C. Sharpe, Matthew W. Brown, et al.

Origin of Spliceosomal Introns and Alternative Splicing

Manuel Irimia and Scott William Roy
Eukaryotic Origins: How and When Was the Mitochondrion Acquired?

Anthony M. Poole and Simonetta Gribaldo

Bacterial Influences on Animal Origins Rosanna A. Alegado and Nicole King

Missing Pieces of an Ancient Puzzle: Evolution of the Eukaryotic Membrane-Trafficking System Alexander Schlacht, Emily K. Herman, Mary J. Klute, et al.

The Neomuran Revolution and Phagotrophic Origin of Eukaryotes and Cilia in the Light of Intracellular Coevolution and a Revised Tree of Life

Thomas Cavalier-Smith

Protein Targeting and Transport as a Necessary Consequence of Increased Cellular Complexity Maik S. Sommer and Enrico Schleiff

How Natural a Kind Is "Eukaryote?" W. Ford Doolittle

For additional articles in this collection, see http://cshperspectives.cshlp.org/cgi/collection/

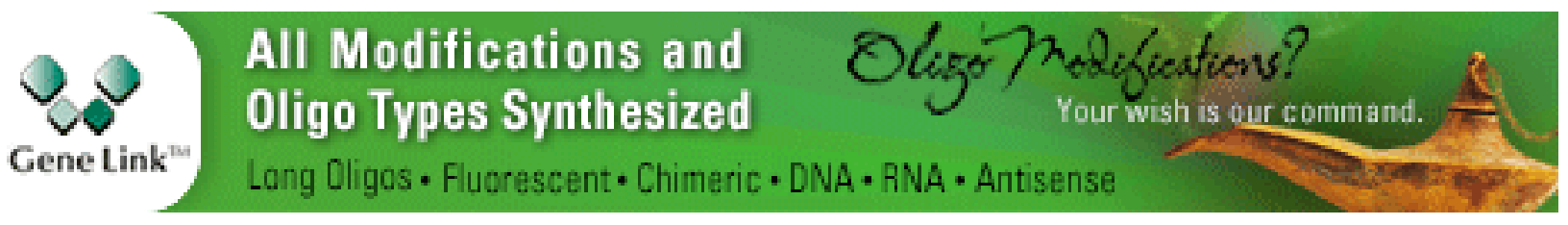


Protein and DNA Modifications: Evolutionary Imprints of Bacterial Biochemical Diversification and Geochemistry on the Provenance of Eukaryotic Epigenetics

L. Aravind, A. Maxwell Burroughs, Dapeng Zhang, et al.

The Eukaryotic Tree of Life from a Global Phylogenomic Perspective Fabien Burki
What Was the Real Contribution of

Endosymbionts to the Eukaryotic Nucleus?

Insights from Photosynthetic Eukaryotes David Moreira and Philippe Deschamps

Bioenergetic Constraints on the Evolution of Complex Life

Nick Lane

For additional articles in this collection, see http://cshperspectives.cshlp.org/cgi/collection/

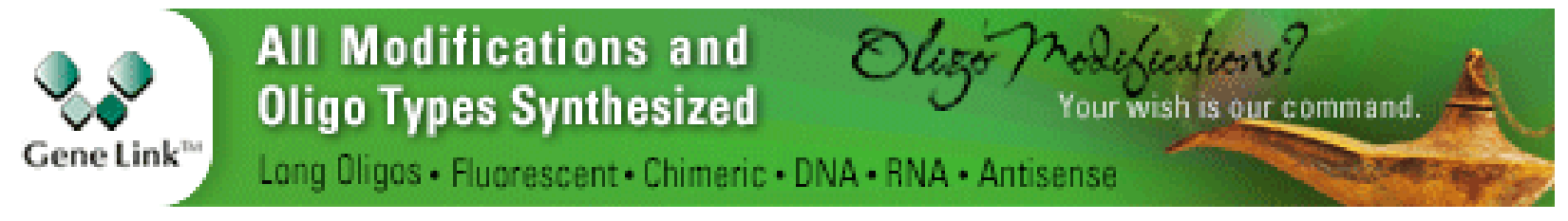

Copyright @ 2014 Cold Spring Harbor Laboratory Press; all rights reserved 